ETO: 821.511.141(497.113)BORI I. 371.671

DOI: $10.19090 /$ hk.2020.3.79-89

\title{
LADÁNYI István
}

\author{
Pannon Egyetem \\ MFTK MANYI \\ Irodalom- és Kultúratudományi Tanszék \\ Veszprém, Magyarország \\ ladanyi.istvan@mftk.uni-pannon.hu
}

\section{A TANKÖNYVÍRÓ BORI IMRE ${ }^{1}$ \\ Imre Bori, the textbook writer}

\section{Autor udžbenika Imre Bori}

A tanulmány Bori Imrének az 1960-as évektől az 1980-as évek végéig kifejtett tankönyvírói munkásságát vizsgálja, összefüggésben a tankönyvszerző irodalomtörténészi kánonformáló tevékenységével. A tanulmány felmutatja a tankönyvíró Bori Imre modernizmus- és avantgárdkutatásainak eredményeit a középiskolai tankönyveiben is, akárcsak a modernizmus fejlödéseszményének érvényesülését az irodalomtörténeti narratívák megteremtésében. A tankönyvek elemzésébe bevonja Bori Imre tanításmódszertani elképzeléseinek publikált dokumentumait is.

Kulcsszavak: irodalomtankönyv, kánon, jugoszláviai magyar irodalom, modernség, avantgárd

Irodalomtörténészi munkásságának eredményeit és tapasztalatait Bori Imre tankönyvíróként is kamatoztatta. Irodalomtörténészi tevékenységével párhuzamosan és az egyetemi magyartanárképzésben végzett oktatói tevékenysége mellett az 1960-as évek közepétől középiskolai tankönyvek szerzőjeként és olvasókönyvek szerkesztőjeként meghatározó szerepe volt a vajdasági magyar közoktatásban szerezhető irodalmi müveltség alakításában. Szeli István mellett a vajdasági magyar tankönyvírás legtermékenyebb szerzője.

\footnotetext{
${ }^{1}$ A tanulmány a Nemzeti Kutatási, Fejlesztési és Innovációs Hivatal - NKFIH támogatásával, A kánonképződés folyamatai komparatív megközelítésben: közép-európai és kelet-közép-európai kánonok a modernség kontextusaiban címü, 125791 nyilvántartási számú NN_17 pályázat keretében készült.
} 
Tankönyvszerzői tevékenysége ideje alatt a vajdasági magyar közoktatásban több reform is végbement. Az 1960-as években és az 1970-esek első felében három iskolatípusban tanultak a középiskolások: négyéves gimnáziumban, négyéves szakközépiskolában (technikumban) és hároméves szakmunkásképző iskolában (Tóth 1982, 1046). Ezekre az iskolatípusokra eltérő tankönyvek készültek. Az 1975/1976-os tanévtől kezdődő indulással országos tanügyi reform keretében fokozatosan átalakítják a középiskolai oktatás szerkezetét. Felszámolják a három iskolatípussal müködö négyéves középiskolai képzést, ehelyett az általános iskolát követően további két általános középiskolai évet vezetnek be a rendszerbe, amit egységesen két szakközépiskolai év követ, megszüntetve ezzel a gimnázium-szakközépiskola-szakmunkásképző hármas rendszerét. A cél a felsőfokú tanulmányokra felkészítő gimnáziumok (a pejoratív értelemben használt elitképzés) és a termelömunkában való közvetlen részvételt lehetővé tévő szakiskolai, illetve szakmunkásképzés különválasztásának megszüntetése. Az egységes szakközépiskolai képzés minden szükséges képzési területet megpróbál lefedni a „munkás-önigazgatás” keretei között megvalósuló „társult munka” igényeinek kielégítésére. A humán érdeklődésü és később a bölcsészettudományi tanulmányokat megcélzó diákok így a továbbtanulásra felkészítő négyéves gimnáziumi tanulmányok helyett a kétéves általános középiskolai tanulmányokat követően különféle humán képzési területeket profilíroz szakirányú középiskolai képzésben vehettek részt, kulturológia, fordító, pedagógia stb. szakirányokon (lásd erről: Tóth 1982; Csorba 1994; Ladányi 2019, 133-135). Ez az iskolarendszer tizenöt-tizenhat nemzedék életét határozta meg, és noha máig viták folynak a mögötte lévő elképzelésekről és gyakorlati megvalósulásukról, az kétségtelennek látszik, hogy a humán müveltségi területeken, különösen pedig a bölcsészettudományi területen továbbtanulni szándékozó diákok vesztesei voltak ennek a reformnak, mert a rendszer nem tudott megfelelően széles és színvonalas müveltséget kialakítani az egyetemi tanulmányok előkészítéséhez, illetve egyáltalán a humaniórákban való elmélyüléshez. A gimnáziumi oktatást 1990-től állítják vissza országosan. Az 1970-es évek közepétől erre az egységes iskolatípusra egységes tankönyveket hoznak létre, amelyek ráadásul szöveggyüjteményi és tankönyvi funkciót is ellátnak, és amelyek terjedelme összesen sem éri el sem a korábbi tankönyvekét, sem a korábbi szöveggyüjteményekét.

Bori Imre és Szeli István kettős szerzőségü könyvei azok, amelyek a régi magyar és a felvilágosodást megelőző világirodalom, valamint a felvilágosodás és a 19. század magyar és világirodalma irodalomtörténeti időszakait fedik le (a középiskolák és a gimnáziumok II. osztálya számára 1964-től 1974-ig, illetve a 
középiskolák I. osztálya számára 1975-től 1986-ig). A kettejük közötti munkamegosztás nem ismert, szakmai érdeklődési területük alapján valószínűsíthető, hogy a régi magyarországi és talán a régi világirodalmi fejezeteket írta Bori Imre, a felvilágosodás és a XIX. század magyar és világirodalmának fejezeteit pedig Szeli István. A II. évfolyamnak szóló, 1975-től megjelenő tankönyv tartalmaz egy irodalomesztétikai és müfajelméleti bevezetőt is, ennek szemlélete Szeli István korábbi I. osztályos gimnáziumi tankönyvére vall. Közösen készítették az Irodalom élete 1967-től 1977-ig megjelenő, IV. osztályos gimnazistáknak írt tankönyvet is, amely az 1945 utáni, tehát akkori kortárs magyar és világirodalommal, a jugoszláviai magyar irodalommal, illetve a délszláv-magyar irodalmi kapcsolatok történetével foglalkozik. Egyedüli szerzője Bori az egységes középfokú nevelés II. osztályos tanulói számára 1976-tól egy kötetben kiadott tankönyvnek és szöveggyüjteménynek, amely a modernség magyar és világirodalmával foglalkozik, illetve a korábban ugyanezzel az időszakkal foglalkozó, külön kötetben megjelent III. osztályos gimnáziumi tankönyvnek és szöveggyüjteménynek. Ahogy irodalomtörténészként is, úgy tankönyvszerzőként is leginkább a modernség irodalmával foglalkozott.

Szakmai viszonyulásában az irodalmi szöveg elemzésére és értelmezésére épülő, fejlődéselvet érvényesítő irodalomtörténeti szempontú megközelítés jellemezte, amely az egyes korszakok újszerü jelenségeire figy lt. Ez összefüggésben állt a modernségre és az avantgárdra irányuló kutatói érdeklődésével, amelyből magáévá tette a modernségnek a folyamatos megújulásra irányuló esztétikai értékrendjét. A későbbi korokból, illetve a kutató jelenkori irodalmiságából kiindulva kutatta a korábbi időszakokban is a később korszakmeghatározónak bizonyuló irodalmi jellemzők előjeleit. A Bori Imre és Szeli István által szerkesztett tankönyvek müközpontúságára jellemző, hogy az 1975-től kezdődően egy könyvbe kényszerülö tankönyv és szöveggyüjtemény mindig az irodalmi szövegeket közlő szöveggyüjteményi résszel indít, és ezeket követik a korábbinál jóval rövidebb irodalomtörténeti összefoglalók. Ez mind Bori Imre, mind Szeli István irodalomszemléletére jellemző, illetve kijelenthető, hogy az „újvidéki iskola" a kezdeteitől fogva ezt a müközpontúságot képviselte.

Bori tankönyvírói nyelve esszéisztikus irodalmi értekező nyelv: az 1965-től több kiadásban megjelent, Az irodalom élete III. osztályos gimnáziumi tankönyv modernségfejezete például nagyszabású esszé az európai és a magyar modern irodalomról, amely számos átjárást mutat Bori ekkoriban íródó tanulmányaival (Bori-Körner 1967; Bori 1969; Bori 1970; Bori 1971). Az egymást követő kiadásokban követhető, hogyan nyer teret az 1960-as évek második felétől tankönyveiben a magyar irodalom avantgárd hagyománya, és Bori avantgárd 
kutatásainak elmélyülésével hogyan kap jelentősebb terjedelmet a klasszikus modernség emblematikus szerzői mellett Kassák Lajos munkássága, Füst Milán költészete és más avantgárd szerzők munkássága, illetve kap figyelmet a magyar irodalomtörténeti köztudatban jellemzően nem elsősorban avantgárd szerzőként számon tartott Déry Tibor fiatalkor szürrealizmusa vagy a tankönyvi megfogalmazás szerint a „szürrealista alapokról indult” ifjú Illyés Gyula. Ugyanezt képezi le a tankönyvvel párhuzamos, Az irodalom könyve címü szöveggyüjtemény is. A középiskolák III. osztálya számára készült 1964-es szöveggyüjtemény még csak két Kassák-verset tartalmaz, a Júliusi földeken címüt és a Mesterembereket, valamint az aktivista Kiáltvány a müvészetért szöveget, az 1970-es kiadás már Kassák hat versét szerepelteti, köztük A ló meghal, a madarak kiröpülnek címü poémát, Füst Milántól öt költeményt, és jelen van az avantgárd kánonon kívül nemigen ismert Barta Sándor is egy verssel, Déry avantgárd versei, valamint Illyés egy szürrealista költeménye. Bori Kassák-tanulmányai az Új Symposion 1965-ös és 1966-os évfolyamaiban jelennek meg, és ezekre épül a Körner Évával közösen írt, 1967-es Kassák-monográfiája, majd további avantgárdpublikációi jelennek meg szintén az Új Symposionban, amelyek eredményeit az 1969-től publikált avantgárdtrilógiájának köteteiben foglalja össze. Ezek az avantgárdkutatások ajánlatot tesznek a magyar irodalomtörténeti kánon olyan átrendezésére, amelyben nagyobb súllyal esnének latba a magyar avantgárd eredményei, ami Bori Imre felfogása szerint egy, az európai irodalmi-mủvészeti folyamatokkal sokkal inkább összhangban lévő képet mutatna fel. Bori a saját tankönyveiben érvényesíti is ezt a képet. Mindez nem független Borinak a jugoszláviai magyar irodalomról kialakult képétől, illetve az általa is alakított önreprezentációjától (pl. A jugoszláviai magyar irodalom rövid története egymást követő kiadásaiban). Ebben jelentős szerep jut a mind a magyar, mind a délszláv avantgárddal kapcsolatokat ápoló, az első világháborút követően az újvidéki Út folyóirat körül csoportosuló avantgárd körnek, akárcsak az 1960-as években felnövő symposionistáknak.

Bori Imre ezzel párhuzamosan alakította ki a jugoszláviai magyar irodalomról szóló narratíváját, amelyet először A jugoszláviai magyar irodalom története 1918-1945 címü kötetében foglalt össze 1968-ban, aztán az Irodalmunk évszázadai 1975-ös kiadásában teljesített ki, majd A jugoszláviai magyar irodalom rövid története 1982-től megújuló kiadásaiban bővített tovább (lásd erről Ladányi 2019, 138-139). A magyar és a vajdasági avantgárdra irányuló kutatásai tudatos hagyományválasztásnak látszanak, amit saját interpretációja szerint a symposionisták fellépése inspirált. 2004-es, utolsó interjújában úgy fogalmaz, hogy azért kezdte közölni az Új Symposionban a magyar avantgárddal 
foglalkozó tanulmányait, „hogy az Új Symposionistá-k törekvései mögé egy kis irodalomtörténeti hátteret is adjunk, és biztatást, hogy amit akarnak, abban van valami fantázia" (Bori 2004, 893). Ha fenntartásokkal is kezeljük a több évtizeddel korábbi saját indíttatásokat értelmező nyilatkozatot, Bori ekkori és ezt követő kutatási témái, különösen a vajdasági magyar avantgárd hagyományok kutatása és fölértékelése a jugoszláviai magyar irodalom történetéről szóló monografikus munkájában voltaképpen a symposionisták föllépésének irodalomtörténeti előzményeit létesítik, sőt ebben az összefüggésben térségi előzményként jelennek meg a Kassákékkal és a Csuka Zoltán-féle $U t$ folyóirattal is kapcsolatban lévő délszláv avantgardisták is. Ezzel az Új Symposion alapvetően kortárs magyar és délszláv kapcsolódásait történeti dimenziókba helyezi. Ezt láthatjuk Az irodalom élete tankönyv negyedikes gimnazistáknak szóló 1967-es kiadásában is, ahol a jugoszláviai magyar irodalom modernisztikus fejlődéselv szerint megvalósuló és az Új Symposionhoz eljutó útját így vázolja fel:

A hatvanas évektől ismét jelentős fordulat áll elő az irodalmi életben, amelynek legfőbb külső jegyei a könyvkiadás igen nagy mérvü fellendülése, az irodalom erőteljes differenciálódása, a fiatal írók feltűnése, az addigi irodalmi orgánumok alkalmazkodása az új helyzethez (a napi- és hetilapok irodalmi mellékleteinek rendszeresebbé válása), majd az újszerü esztétikai felfogás térhódításának legfontosabb jeleként az Új Symposion c. folyóirat megjelenése. A belső változások még szembetünőbb jelei az ún. „tájirodalommal” és a provincializmussal való gyökeres szakítás óhaja, a szellemi horizontok kitágulása az egyetemes jugoszláv és az európai irodalom felé, a társadalmi és szellemi folyamatok magas irodalmi síkon való igényes kifejezése, a modern magyar irodalom rokontörekvéseinek megértő befogadása s az ezekből adódó gondolati, müvészi, formai következmények levonása és vállalása (Dr. Bori-Dr. Szeli 1967, 85).

Az 1967-ben megjelent tankönyvben az akkor negyedikes gimnazisták már tanulhattak a két évvel azelőtt indult folyóiratról és néhány, a húszas évei végén járó szerkesztőjéről és szerzőjéről. Külön bekezdést kap benne a symposionisták közül az 1937-es születésü Fehér Kálmán, az 1939-es Bányai János és egy felsorolás erejéig az 1940-es Tolnai Ottó, Domonkos István, az 1943-as Brasnyó István, az 1937-es Koncz István. Bori Imre és Szeli István 1972-es, IV.-es gimnazistáknak szóló szöveggyűjjteménye pedig tovább aktualizálja a vajdasági magyar irodalom kortárs fejleményeiről alkotott képet, és a középgeneráció szerzői (Ács Károly, Fehér Ferenc, Major Nándor) mellett közli Domonkos István és Tolnai Ottó egy-egy versét is, amelyek a fiatal szerzőknek a magyar 
kultúra modern zenei hagyományai iránti érdeklődését tanúsítják: Domonkos Bartók Béla címü költeményét és Tolnai Ottó Kodály címü poémáját.

Ezek a tankönyvek tehát mind a magyar, mind a jugoszláviai magyar irodalom vonatkozásában kánonalakítók, és különösen a jugoszláviai magyar kultúra vonatkozásában identitásformálók is. A tankönyvszerzők igyekeznek tudatosítani és alakítani a jugoszláviai magyar közösség sajátos helyzetét, értékesként mutatva fel a közösség irodalmi örökségét, támogatják a diákokat mind magyar, mind jugoszláviai magyar identitásukban, erősítve ugyanakkor a jugoszláviai folyamatokhoz tartozásukat is.

Ebben az 1967-es tankönyvben a délszláv-magyar kapcsolattörténeti fejezet nemcsak történeti áttekintést, hanem komparatisztikai elméleti megfontolásokat is megfogalmaz, arról értekezve, hogy

[a]z irodalmi egymásra hatások történetének és természetének vizsgálatakor soha sem elégedhetünk meg az átvett motívumok, a kölcsönzött téma vagy fabula egyszerü kimutatásával, hanem azt kell megállapítanunk, hogy az átvevő, a kölcsönző irodalom magába fogadta-e, asszimilálta-e, egyéniségének részévé tette-e az átvett tárgyat, motívumot vagy kifejezési formát. Az irodalmak egymáshoz való viszonyát tehát nem az ,átvételek” vagy „hatások” külső megnyilvánulásai szerint kell megítélnünk, hanem aszerint, hogy a „,befogadó” irodalom hogyan alakította át a maga ízlésének, egyéniségének és szerves életének megfelelően az ,átadó” irodalom elemeit. E tekintetben pl. ma már egészen világos előttünk, hogy miben „hatott” és milyen indítékokat szolgáltatott a szerb népköltészet, az ún. „szerbus manír” a múlt század harmincas éveiben a magyar népi és nemzeti irodalmi törekvésekre, amit - mint Horváth János mondja - „Vörösmarty tett irodalmunk sajátjává, ő lehelt rá egy ezentúl örökké velejáró stílhangulatot, ö öntötte el megfelelö, a magyar népies naivságban is otthonos, de a maga nagyszerü ihletén ünnepivé magasztosult, gyöngéd választékossággal”. Ugyanígy az irodalomtörténet azt is tisztázta, hogy milyen ihletforrást nyújtottak és miben támogatták Jovan Jovanović Zmaj ars poeticáját, ízlését és irodalmi programját a magyar „nemzeti klasszicizmus” költői megvalósulásai, különösen pedig Petőfi és Arany költészete. Annak a felmérése azonban, hogy mit jelentett a magyar irodalommal való termékeny érintkezés nemcsak Miroslav Krleža, Miloš Crnjanski vagy Veljko Petrović, hanem a mai jugoszláv írók munkásságára nézve, vagy hogy milyen visszhangja van a magyar irodalomban a mai jugoszláv irodalmi és esztétikai törekvéseknek, mindez még a jövő feladata (Dr. Bori-Dr. Szeli 1967, 97). 
Az idézet nemcsak komparatisztikai elméleti és módszertani ismereteket közöl, illetve ezzel összefüggésben irodalomtörténeti ismereteket közvetít, némiképp a diákság saját, a magyar kultúra mellett a délszlávban is többé-kevésbé jártas helyzetének adva történeti dimenziókat (illetve megfordítva is: az irodalomtörténeti anyag sajátos aktuális visszhangját lehetővé téve), hanem lehetséges jövőbeli feladatokkal a diákság érdeklődő részét az irodalommal való szakmai foglalkozás élő folyamataiban is érdekeltté kívánja tenni. Hogy mennyire tudatos munkáról van itt szó, azt tanúsítják Bori Imre 1968-ban írt Tankönyveink és A modern magyar irodalom a középiskolában című cikkei (Bori 2000, 31-33; 56-66). A modern magyar irodalom a középiskolában címü tanulmányában a pedagógiai szemléletváltás szükségességéről ír, a tanár folyamatos önképzését és tájékozódását szorgalmazva, olyan korszerü pedagógiai elvárásokkal, amelynek keretében a tanár nem tananyagot tanít, hanem olvasói élmények megszerzését teszi lehetővé a diákjainak, vezetve és támogatva őket a saját tanulásukban: ,,mind kevésbé lehet irodalomtörténetet előadni, és mindinkább az irodalom tanulmányozásának a feladata kerül elötérbe, a tanulónak mindinkább olvasói élményekkel kell találkoznia, s mind kevésbé foglalkozhat a XX. század magyar irodalmával »tananyagként« a szó régi pedagógiai-módszertani értelmében” (Bori 2000, 61). Az évek során egymásra épülő olvasóvá nevelést szorgalmaz, hogy a harmadik és különösen a negyedik gimnáziumi évben a tanárnak már egyre inkább ne tanítania kelljen, hanem „vezetnie” a diákjait. „A modern irodalom tanításánál [...] az iskolai óra nem az ismeretszerzés kiindulási pontja, hanem a végpontja” (Bori 2000, 62), foglalja össze tankönyvírói tapasztalataira épülő pedagógiai elvárásait.

Tanulságos az egyes évfolyamok számára készült Bori-tankönyvek összevetése a több évtizedes tankönyvírói pályafutás során. Míg az 1960-as évek második felében és az 1970-esek elején a saját irodalomtörténeti kutatások és kortárs irodalmi tájékozódások gyors beépülése jellemző tankönyveire, az 1970-es évek második felétől az egyes tankönyvek évenkénti újrakiadásai hosszú évekig változatlan utánnyomást jelentenek. Bori Imre társszerző nélkül, egyedül írta az 1970-es évek második felétől az 1980-asok végéig használt II. osztályos irodalomkönyvet, amely a modern világirodalommal és a magyar modernség irodalmával foglalkozik a századfordulótól a 20. század közepéig, Weöres Sándor és Tamási Áron munkásságáig. Az iskolareform előtti időszakban ez az anyag még a harmadikos tankönyvben volt, mert az első évfolyam számára ekkor még nem irodalomtörténetet tanítottak, hanem egy korszakoktól független bevezetést az irodalomba mint müvészetbe, müfaji, poétikai és retorikai fogalmakkal, müértelmezéssel. 
Szembetünő, hogy a másodikos tankönyv a hetvenes évek második felétől a nyolcvanasok végéig változatlan utánnyomásokban jelenik meg, lényegében csak az impresszuma változik. Izgalmasabb ennek a tankönyvnek az összevetése Bori korábbi, harmadikos gimnazistáknak írott Az irodalom élete tankönyvével. Az irodalom élete tankönyv 1970-es második, átdolgozott kiadását (Dr. Bori 1970) vetettem össze Az irodalom könyve ekkor már szöveggyüjteményt és tankönyvet egyben tartalmazó 1987-es kiadvány tankönyvi részével (Dr. Bori 1987). Szembetűnő, hogy Bori szinte változatlanul használja fel korábbi tankönyvének szövegeit, csak szerkezeti módosításokat alkalmaz. 1987-es Baudelaire-, Thomas Mann- vagy Kafka-fejezete szó szerint megegyezik az 1970-es tankönyvében lévővel. Ezek az életmü-összefoglalók valóban nem évültek el, legfeljebb beszédmódjuk kevésbé rezonál az 1980-as évek közepe kamaszainak világára. Becsúsznak viszont olyan szerkesztési figyelmetlens gek, amelyekkel az életmü-összefoglalók korábbi egymásra épülő sorrendjének megváltozása miatt egyes belső utalások érvényüket vesztik. Míg korábban a Kafka-fejezet megelőzte a Thomas Mannról szólót, így a Thomas Mann-fejezet visszautaló indítása összefüggés-teremtő lehetett a tanulók számára („Franz Kafka az Idő és a Tér viszonylatait álom-keretbe foglalta, nemcsak szubjektívvá tette, hanem megfosztotta valóság-jellegétől is. Thomas Mann [1875-1955] realitásként igyekszik értelmezni, s természettudományos ismérveit tisztelve realitásától sem fosztja meg" [Dr. Bori 1987, 159, illetve a korábbi tankönyvben: Dr. Bori 1970, 25]). A fejezetkezdő idézet a korábbi tankönyvben a megelőző Kafka-fejezet utolsó bekezdésére utal: „Franz Kafka müvészetének sajátossága, hogy »tárgyias, gondos, aprólékosan részletező elemző leírásai álomszerü, vízionárius (sic!) képtelenségeket rögzítenek «, azaz: jeleneteinek kerete álom- és látomásszerü, apró részletei pedig kínos tárgyilagossággal és realitás-érzékkel készülnek. Regény-technikája tehát kontrasztokra épül, a »részletek ésszerüségének látszólagos voltát az egész ésszerütlensége leplezi«" (Dr. Bori 1970, 25). A két bekezdés egymást követően összefüggést teremt, sorrendjük fölcserélésével viszont távol kerülnek egymástól, és ezeket a kapcsolatokat legföljebb a tanár hathatós segítségével építhetik föl. A szovjet irodalomról készített fejezete viszont a későbbi könyvben már lerövidül, és első bekezdésében ugyan az 1987-es tankönyvében is felmondja a korábbiból átvett kötelezőt az októberi forradalomról, hogy az „a világtörténelem egyik legnagyobb jelentőségü eseménye volt", de Gorkijt mellözi, csak Solohov Csendes Donjával foglalkozik, illetve a Majakovszkij-bekezdéseket is kihagyja, csupán a futurizmusról írtak között hagyja meg a rá vonatkozó mondatot. Figyelemre méltó ugyanitt A novella a századvégen fejezet alakulástörténete is. A szövegében jelentösen 
megegyező későbbi változat mellőzi Petelei Istvánt, Gozsdu Eleket, beiktat viszont három érdemi bekezdést Csáth Gézáról. Míg a hatvanas évek végén, a hetvenesek legelején ezt Bori nem látta időszerünek, és a Csáth-kutatások is éppen csak elindultak Dér Zoltán révén, a hetvenes évek folyamán kezdett élénkülni a Csáth iránti érdeklődés, Borinak is fontos szerzője lesz a jugoszláviai magyar irodalom előtörténetének koncepciójában és a századelő modern prózáját kutatva is. 1971-ben már publikál az Éjszakai esztétizálásról (Bori 1971, 1063-1065), továbbá az 1977-es Varázslók és mákvirágoknak is fontos szerzője Csáth (Bori 1977, 267-309). Itt is tetten érhető tehát Bori Imrének az a tankönyvszerzői hozzáállása, hogy újabb kutatási eredményeit haladéktalanul beépíti tankönyveibe, érvényesítve a maga kánonelképzeléseit.

Más szempontból tanulságos a magyar modernizmus és nemzetközi összefüggései tanításában nagy hangsúlyt kapó Ady Endréről írt fejezetek összehasonlítása. Az 1970-es tankönyv komplett Ady-esszéje nyugodtan építkező, kifejtö, adatgazdag áttekintés az életmüről és a nemzetközi modernizmusba való beágyazottságáról tizenhat illusztrációk nélküli tankönyvoldal terjedelemben (illusztrációkat a szöveggyüjtemények tartalmaznak). Az egységes középfokú oktatás számára készült új tankönyve teljességében a korábbi szövegét használja, megfogalmazásai csak jelentéktelen mértékben módosulnak az átvett szövegegységekben, így természetszerüleg szemléleti különbségek sincsenek. Ugyanakkor a későbbi, szöveggyüjteményt és tankönyvet is tartalmazó könyv Ady-fejezete jóval rövidebb (illusztrációkkal együtt kilenc tankönyvoldal), a korábbi változatnak mintegy a fele, és ebböl következőleg kevésbé kifejtettebb. Különösen az 1970-es esszének az Ady-vers karakteréröl szóló összegző alfejezete hiányzik, amelyben az avatott irodalomtörténész mintegy bevonta a kortárs Ady-értelmezések folyamataiba a gimnazistákat, a fentebb vázolt pedagógiai elképzeléseinek megfelelően. Itt láthatólag terjedelmi korlátok érvényesültek a szöveggyüjtemény- és tankönyvfunkciót egyszerre ellátó későbbi kiadványnál.

A két könyv részletes összehasonlítása azt mutatja, hogy a második szinte teljesen a korábbinak a szövegét használja, sorrendi változtatásokkal és a korábbi szöveg jelentős rövidítésével. Az 1970-es tankönyv bőséges, diskurzusában nyugodt, valamint következetesen egymásra épülö, korszerü áttekintést ad a modernizmus világirodalmáról és magyar irodalmáról. A későbbi változat az átrendezések és rövidítések ellenére még mindig jól használható tankönyv, de korántsem olyan innovatív, mint másfél évtizeddel korábbi elődje.

Összegzésként Bori Imre (és szerzőtársa, Szeli István) tankönyveiről elmondható, hogy a leginnovatívabbak az 1975-ben indult reform elötti könyveik, amelyek szemléletükben újszerüek, szelekciójukban a magyar irodalomtörténeti kánon 
követése mellett kezdeményezők a kánon átalakításában is, a kortárs világirodalmi és magyar irodalmi anyag bemutatásában pedig kifejezetten aktuálisak, kánonformálók. Jellemzi őket a magyar irodalomnak az európai kultúrkörhöz való odatartozásának láttatása, beszédmódjukban a modernizmus fejlődéseszményének érvényesítése, a kortárs irodalmi változások felé való nyitás, az irodalom mint élö, változó rendszer érzékeltetése. Az új iskolatípusokhoz illeszkedő tankönyveik a szükebb terjedelem ellenére is megpróbálják átmenteni korábbi tankönyveik értékeit, és szelekciójuk legalább az első kiadások idején továbbra is aktuális. Az 1980-as években megjelenő ismétlődő kiadások és tankönyveik későbbi, az ezredfordulóig megjelenő átdolgozásai már kevésbé képesek a megújulásra, és voltaképpen saját korábban kialakult irodalmi ízlésüket reprezentálják, a bemutatott anyag szelekciójában sem újulnak meg, és messze elmaradnak a korábbi tankönyvek frissességétől. Mindez részben magyarázható azokkal a kötöttségekkel, amelyek az 1975-töl érvényesített oktatási keretek és tanterv másfél évtizedes időszakában jelen voltak, amikor az irodalomtanításra fordítható óraszám és a tankönyvi terjedelmek csökkenése mellett például a jugoszláviai népek és nemzetiségek irodalmára vonatkozó kvóták is megkötik a tankönyvszerzők kezét. A tankönyvekben csekély mértékben érzékelhetők az ideológiai keretek, jelen van például az irodalom társadalmi meghatározottságainak, „tükröző” jellegének felfogása, de egészében dominál az irodalmi müalkotásra koncentráló, a müvek poétikai jellemzőire figy lő, müértelmezést szorgalmazó olvasói viszony, a kortárs irodalom kapcsán pedig kifejezett kockázatvállalás, az élő irodalom közelségének, változékony természetének, az értelmezés lezáratlanságának az érzékeltetése.

\section{Irodalom}

Bori Imre. 1971. Csáth Géza: Éjszakai esztétizálás. Tiszatáj 25 (11): 1063-1065.

Bori Imre-Körner Éva. 1967. Kassák irodalma és festészete. Budapest: Magvető.

Bori Imre. 1969. A szecessziótól a dadáig. Újvidék: Forum.

Bori Imre. 1970. A szürrealizmus ideje. Újvidék: Forum.

Bori Imre. 1971. Az avantgarde apostolai. Újvidék: Forum.

Bori Imre. 1977. Varázslók és mákvirágok. Újvidék: Forum.

Bori Imre. 2000. Identitáskeresőben. Újvidék: Forum.

Bori Imre. 2004. A szabadabb szemlélet jegyében. Bori Imre utolsó interjúja. Készítette: Franyó Zsuzsa. Híd 68 (7): 890-893.

Csorba Béla. 1994. A lábadozástól az elsorvadásig: A vajdasági magyar iskolaügy a második világháború után. Regio: Kisebbség, politika, társadalom 5 (1): 96-117. 
Dr. Bori Imre. 1970. Az irodalom élete: A gimnáziumok III. osztálya számára. Második, átdolgozott kiadás. Novi Sad: Tartományi Tankönyvkiadó Intézet.

Dr. Bori Imre. 1987. Az irodalom könyve: Egységes középfokú nevelés és oktatás II. osztálya számára. Negyedik kiadás. Újvidék: Tankönyvkiadó Intézet.

Dr. Bori Imre-Dr. Szeli István. 1967. Az irodalom élete: Tankönyv a gimnáziumok IV. osztálya számára. Novi Sad: Tartományi Tankönyvkiadó Intézet.

Ladányi István. 2019. Jugoszláviai magyar irodalom-tankönyvek és az irodalmi kánon. In Kánon és komparatisztika: A kánonok többszólamúsága kelet-közép-európai kontextusban, szerk. Földes Györgyi és Szávai Dorottya. 133-147. Budapest: Gondolat Kiadó.

Tóth Lajos. 1982. A József Attila Tudományegyetem egységes kísérletének a vajdasági iskolareform szemszögéből való összehasonlító vizsgálata. Létünk 12 (6): 1045-1067.

\section{IMRE BORI, THE TEXTBOOK WRITER}

The study examines the work of Imre Bori as a textbook writer in the context of the canon forming literary history activity of the textbook writer author from the 1960 s to the end of the 1980s. The study also presents the results of the textbook writer Bori's research on modernism and the avant-garde in his secondary school textbooks, as well as the effectivene s of the ideal of the development of modernism in the creation of literary historical narratives. The analysis of the textbooks also includes Imre Bori's published documents on his methodological ideas in teaching. Keywords: literary textbook, canon, Hungarian literature in Yugoslavia, modernity, avant-garde

\section{AUTOR UDŽBENIKA IMRE BORI}

Studija se bavi pisanjem udžbenika Imrea Borija od početka 60 -ih do kraja 80 -ih godina 20. veka, u sprezi sa njegovim aktivnostima u oblasti istorije književnosti, gde je Imre Bori formirao kanone. Studija predstavlja rezultate istraživanja modernizma i avangarde Imrea Borija i u srednjoškolskim udžbenicima, kao i afirmisanje ideala razvoja modernizma u stvaranju književnoistorijskih narativa. U analizu udžbenika su uključena i publikovana dokumenta koja sadrže Borijeve ideje o metodici nastave. Ključne reči: udžbenik književnosti, kanon, mađarska književnost u Jugoslaviji, moderna, avangarda 